\title{
Problems and Improvement Methods of Vocational Skill Appraisal in Applied Colleges and Universities
}

\author{
Juan Duan, Yi Wang \\ Chongqin City Management College, Chingqin, 413000, China
}

Keywords: Applied colleges and universities; vocational skill appraisal; problems; improvement methods.

\begin{abstract}
At present, colleges and universities pay more attention to the cultivation of applied talents to meet the needs of comprehensive talents in various fields. In the cultivation of talents in colleges and universities, it is necessary to break the traditional theoretical teaching mode and start teaching from the perspective of student's profession, so that teaching can be carried out around the needs of students, including knowledge needs, vocational needs, and the needs of qualification certification. Colleges and universities not only teach students professional knowledge, but also need to pay attention to the cultivation of technical abilities, and formulate and implement the vocational qualification certificate system in colleges and universities, so that students have a certain practical ability, and through the vocational skill appraisal, they will have the post admission qualifications and can be smoothly employed after graduation. From the current situation of vocational skill appraisal in applied colleges and universities, there are still some problems, which require colleges and universities to combine the theoretical teaching and practical teaching of students, so as to improve the ability of vocational skill appraisal, and only the effective integration of the three are achieved can put forward the improvement strategies from problems. In this paper, it focuses on the problems and improvement methods of vocational skill appraisal in applied colleges and universities.
\end{abstract}

\section{Introduction}

Applied universities focus on training technical talents. Judging from the current talent demand in current enterprises and engineering fields, the quality standards for technical talents are no longer limited to the technology itself, but also the abilities of operation and management are required. Therefore, in order to ensure the quality of talents in the cultivation of applied talents in colleges and universities, it should pay attention to the combination of theoretical education and practical education of students, but also cultivates the talents from the perspective of students' vocational needs. Nowadays, many vocational posts require people to have professional qualification certifications, so in the cultivation of talents in colleges and universities, in addition to conduct the professional education towards students, it needs to pay attention to students' vocational and technical ability training, establishes vocational qualification certificate system, and combines the teaching and technical training. For colleges and universities, they have long attached importance to the theoretical and practical education of students, so that in order to do a good job in vocational skill appraisal, they must break the original mode of higher education, and improved the vocational skill appraisal system.

\section{Problems Existing in the Process of Vocational Skill Appraisal in Applied Universities}

\subsection{No Fully Understanding on the "Double Certificate" System}

In the cultivation of talents in applied universities, besides professional training, the vocational education of students also needs to be focused, so after students finish their studies and graduate from universities, they can not only obtain diplomas, but also obtain vocational qualification certificates, which can meet the educational needs of students and provide good conditions for their employment. 
The applied universities adopt the "double certificate" system in the cultivation of talents mainly from the perspective of education, so they ignore the recognition of enterprises and the society, which makes the society and enterprises do not fully accept the "double certificate" system in colleges and universities, and the "double certificate" cannot be fully used after students entered the talent market.

From the current implementation of "double certificate" system, it is often too formal. Although students have diplomas and professional certificates, they still do not play an advantage in the occupational field, and gradually, students no longer have confidence in the "double certificate" system.

The labor departments in the area where the universities are located neither establish cooperative relations with the universities, nor realize the jointing between universities and enterprises, which makes the skills and abilities of students do not meet the talent needs of enterprises after receiving the professional training of universities.

\subsection{The Importance of Vocational Skill Appraisal in Colleges and Universities is not enough}

Colleges and universities implement the vocational skill appraisal system, but are not widely developed. They mainly aim at some majors with strong specialization and technicality, so the number of students involved in relatively small; therefore, it is obvious that colleges and universities do not pay enough attention to vocational skill appraisal.

Judging from the current situation of vocational skill appraisal in colleges and universities, skill appraisal has become a form mainly because the lack of equipment and facilities for technical ability appraisal and the appraisal site cannot meet the conditions, and students are not actively aware of participating in skill appraisal.

Due to the technical ability appraisal does not have the comprehensive coverage in the scope of colleges and universities, and the number of students participating in the appraisal is unstable (sometimes there are a lot of people, and sometimes there are very few people), in addition the vocational work types of students participating in the appraisal are not uniform enough (some majors do not need to participate in the appraisal), making students ignore the importance of obtaining vocational skill certificates.

\subsection{Vocational Skill Appraisal does not Fully Integrate with Practical Teaching in Colleges and Universities}

In the teaching of applied universities, the combination of theoretical teaching and practical teaching has been realized; however, in the process of practical teaching, it is not combined with vocational skill appraisal and is realized independently, which makes the cultivation of students' technical operation ability in the process of practical teaching is not carried out from the perspective of occupations. Although students have professional qualification certificates, the certificates do not meet the needs of the current industry. Students will waste a lot of time in the training of obtaining certificates during the study period, and the corresponding practical and technical ability is not enough, which means that there is a lag in vocational skill qualification examination in colleges and universities, and it is not in line with the actual production of enterprises and the technical standards of talents.

\subsection{Technical Training and Appraisal Skill Training are not Strictly Distinguished in Colleges and Universities}

In the practical teaching of colleges and universities, students' operational training of technical ability is often confused with technical ability training, but in fact, there are many differences between them. Some majors don't need a skill certificate, so it is a waste of time to receive training in schools for obtaining a qualification certificate. Some students will also get certificates which are not directly related to their majors, but holding qualification certificates without technical ability cannot directly represent the technical ability of students.

Colleges and universities do not bring the professional ability certificates into the teaching system, so in order to obtain the qualification certificates, students need to sign up for training before carrying 
out skill appraisal, which not only takes a lot of time and effort, but also costs money. This way of separating training and appraisal inevitably violates the original intention of skill appraisal.

\section{Improvement Methods of Vocational Skill Appraisal in Applied Universities}

\subsection{Further Strengthening the Labor Access System}

With the further strengthening of labor access system, the vocational qualification certificate is no longer a formal certificate, but has a substantial meaning and is more valuable.

Due to the labor access system has not been actively implemented, and has not achieved "training first, then going to the post", so even if the personnel on the post received training, they did not receive strict examination, which makes the vocational qualification certificate system not play an effective role in talent training and cannot effectively represent the ability of talents. Therefore, the labor access system should be further strengthened, that is, when introducing talents, the system of holding certificates before going to the post needs to strictly required on the technical posts of enterprises. Enterprises attach importance to the work of labor supervision, strictly implement the vocational qualification certificate system from the professional position, and need to start from the professional posts related to students' major to promote the employment of talents in the process of implementing the "double certificate" system.

In addition, we should also increase the publicity of vocational qualification certificates, so that students will participate in vocational skill appraisal independently from their own majors, and have accurate understandings for the vocational skill appraisal. Colleges and universities should combine practical teaching with vocational skill appraisal, attach importance to student's practical ability, create various conditions for students to get employed smoothly, and let students enter enterprises to participate in technical training, contact with the production environment, and understand the first-line management model of enterprises. It is very helpful for student to improve practical ability if they have the opportunity to contact with enterprises during the period of school. Colleges and universities can establish off-campus training bases to combine production, research and teaching from the perspective of industry, integrate the content of vocational qualification examination into teaching and carry out according to the plan, combine the practical activities with national vocational skill appraisal, and turn vocational skill appraisal into the assessment of students' practical learning, so that to make the vocational qualification certificate have a substantial meaning.

\subsection{Integrate the Vocational Ability Training into the Teaching Process}

Integrating the vocational ability training into the teaching process will combine the practical teaching with the vocational skill appraisal in colleges and universities and will improve students' skills and quality, so that the purpose of college students' employment service can be implemented. Colleges and universities establish the cultivation of talents on the basis of combining production, learning and research, continuously innovate the talent training program, cultivate talents starting from improving students' technical ability, and systemize the educational model of combining theory with practice, which not only strengthens the practical teaching, but also makes the vocational qualification certificate more valuable.

In teaching, colleges and universities should not only optimize the teaching content, but also constantly adjust the teaching structure to combine the vocational certificate courses with the teaching plan, to perfect the vocational standards, and to embody the vocational certificate courses in the teaching syllabus. In the training plan of colleges and universities, the correlation between the teaching content of the students' professional theory courses and the professional standards should be established, the practical courses should be carried out in the mode of cultivating the teaching ability, and the training of students' skill operation should be conducted according to the technical ability standards in the field of the industry.

Colleges and universities can set up a major of professional qualification certificate, and in the training of students, all courses and be carried out according to the plan, so that students can realize 
the effect of professional qualification certificate, including the types and levels, etc. For the training project, it can carry out a separate assessment and assign credits, so as to improve the attention of students, and to achieve the organic combination of vocational qualification certificate and students' professional education.

\subsection{Professional Teaching Content Should Link up with the Vocational Skill Appraisal in Colleges and Universities}

Colleges and universities should link up the teaching of students' professional courses with the vocational skill appraisal. In the specific implementation process, colleges and universities should formulate professional qualification standards to integrate into the syllabus, and should have teaching plans. In the process of developing professional theory teaching, colleges and universities should combine it with practical teaching, fully implement the vocational qualification standards, and students can improve their skills after completing their professional courses in colleges and universities, so that the academic education can be combined organically with the vocational qualification training. The following points need to be done.

Firstly, the curriculum structure should be constantly improved, vocational skill training should be carried out according to the syllabus, examination content should be brought into the students' curriculum education system, and curriculum teaching content should be characterized and professionalized.

Secondly, when arranging the teaching content, it should be combined with the vocational qualification certification system to combine the teaching knowledge with the technical ability.

Thirdly, the curriculum content is updated from the quality standards of professional positions to ensure that the knowledge students learned is leading in the industry, so that when the students enter the position, they will be useful and play their own professional values. Therefore, it is necessary to continuously update knowledge according to the needs of industry in the training of students' technical ability.

Fourthly, in the selection of teaching materials, it is necessary to carry out from the position ability of students. The content of teaching materials should be directly related to the content of professional post, and the content of teaching materials should be selected in strict accordance with the talent quality standards of the professional post. The preparation of teaching materials combines with the industry standards to constantly update knowledge, and to play the practical role of teaching materials.

\subsection{Colleges and Universities Should Pay Attention to the Cultivation of Teachers' Comprehensive Quality}

In order to improve the level of vocational skill appraisal, colleges and universities must pay attention to the cultivation of teachers' comprehensive quality. Teachers must meet the conditions of ordinary higher education teachers, and all aspects of them must meet the requirements of vocational skill appraisal.

The education of colleges and universities is not only responsible for theoretical teaching, but also requires a high level of professional skills to cultivate students' practical and operational skills. Nowadays, if students want to improve their professional abilities, they must not only have practical operation abilities, but also have theoretical application abilities, so teachers not only can teach students in classrooms, but also can play the role of engineers to guide students' theory and to ensure vocational skill training.

In the specific work, it needs to pay attention to the post training of college teachers and improve the professional level of teachers, and it is necessary for teachers to actively participate in practical training, to study regularly in enterprises, to strengthen technical ability training, and to improve operational abilities and the level of teaching guidance.

In the cultivation of students' practical ability, current colleges and universities generally cooperate with enterprises to establish a school-enterprise cooperation relationship, and carry out teaching towards students for hiring engineers from enterprises to colleges and universities. In order 
to cultivate talents to meet the needs of enterprises, colleges and universities should establish cooperation relationship with enterprises to cultivate technical talents who are skilled in operation. The school is a talent base to play a role in transmitting knowledge, and the enterprise is the practical base to play a role in technical guidance. Combining colleges and enterprises and sending teachers to enterprises for investigate, internship, and on-the-job training will help improving the comprehensive quality of the teaching staff.

\section{Conclusion}

To sum up, in the cultivation of college students' vocational ability, the cultivation of technical ability and professional teaching should be combined to make the cultivation of talents in colleges and universities is no longer the teaching of professional knowledge, but the combination of technical ability training, professional teaching and professional qualification certification. Adopting this interactive teaching mode, the integration of subject, occupation and qualification certification is realized, so when students finish their studies in colleges and universities, they not only get academic qualifications, but also can grasp the direction of their careers, and their employment competitiveness is enhanced with the qualification certificates recognized in the professional field. In studying, the professional knowledge can be combined with their occupations, so on the one hand, the employment channels of students have been broadened, on the other hand, the talents cultivated by colleges and universities have met the needs of the talent market.

\section{References}

[1] Shi Jingpu, Xie Hui. Marketization of Vocational Skill Appraisal Institutions in Applied Universities Under the "New Normal". Time Education, 2016(24):9-10.

[2] Wang Jiaqing, Guo Xiaofan. Exploration and Practice of Vocational Skill Appraisal in Applied Universities, Modern Vocational Education, 2017(07):57-58.

[3] Shi Jingpu. Enlightenment of "Dual System" Education to the Vocational Skill Appraisal Institutions in Applied Universities, New West, 2016(15):164-164.

[4] Wang Jiaqing, Guo Xiaofan, Fu Yujie. Value and Status of Vocational Skill Appraisal in Applied Universities, Contemporary Education Research and Teaching Practice, 2017(11):37-38.

[5] Huang Wendan. Exploration on Strengthening the Vocational Skill Training Appraisal in Modern Applied Universities, Learning Week, 2015(36):25-25. 